\title{
Digital Marketing in Promoting Bioeconomy in Ukraine
}

\author{
Tkachuk V. I., Zinovchuk V. V., Tarasovych L. V., Yaremova M. I.
}

\begin{abstract}
The article deals with the substantiation of the role and opportunities of involving digital marketing tools for the promotion of the bioeconomy in Ukraine. It is substantiated that the intensification of a socially oriented bio-based business in Ukraine is determined by conveying to the society the necessity to transform the established concept of strategic growth, which will follow not only human-centric but also ecocentric paradigms. The use of modern digital technologies, one of which is digitization, contributes to the above.

It is empirically proven that socially-oriented and economically justified digitization acquires a permanent status in the field of inclusive growth. The digitization of the bioeconomy against the background of social digital transformation determines the imperatives for the development of the Ukrainian economy, and the digitization of its agricultural sector is considered one of the key tasks of the new government of our country.

In order to visualize the concept of implication of digital marketing in the process of the establishment of the bioeconomy, the criteria for identifying its benefits were systematized; they include the target audience (stakeholders), the sphere of influence on it (exogenous and endogenous business environment) and marketing channels and tools, that is, bioeconomy as a strategic vector for promoting the ecologization of the social and environmental processes of human existence. The expediency of digital marketing tools is determined by the specific conditions, opportunities, needs and tasks of stakeholders in terms of the intensification of bioeconomic processes.

The effectiveness of the implementation of the developed model of digital marketing implication in the field of the bioeconomy will be determined based on the configuration of the corresponding effects in terms of economic, social and environmental benefits, that is, sustainable growth will be ensured according to the synergetic approach. The generalized format of applying digital marketing tools and defining marketing channels for promotion of the bioeconomy will ensure the consolidation of efforts of all stakeholders in order to create favorable conditions for running bio-based business. This is a determinant for the sustainable development of Ukraine and for the civilized development of modern society.
\end{abstract}

Key words: bioeconomy, digitalization, marketing, digital marketing tools, bioeconomic potential, sustainable economic development, inclusive growth.

Revised Version Manuscript Received on October 15, 2019.

Tkachuk V. I., Professor, Head of the Department of Economics and Entrepreneurship, Zhytomyr National Agroecological University of Ukraine, Zhytomyr, Ukraine

Zinovchuk V.V., Professor, Head of the of Marketing Department, Zhytomyr National Agroecological University of Ukraine, Zhytomyr, Ukraine

Tarasovych L.V., Associate Professor, doctoral student at the Marketing Department, Zhytomyr National Agroecological University of Ukraine, Zhytomyr, Ukraine

Yaremova M. I., Associate Professor, doctoral student at the Department of Economics and Entrepreneurship, Zhytomyr National Agroecological University of Ukraine, Zhytomyr, Ukraine

\section{PROBLEM STATEMENT}

The results of globalization include not only the intensification of international cooperation, the increase in the volumes and pace of trade in agrifood products, but also fundamental changes virtually in all spheres of socioeconomic life of society with the focus on the innovative approaches in forming the economic foundation for business, including agricultural business. World trends in the development of the economy prove the necessity to actively involve innovative levers for regulating socioeconomic processes. This refers to expanding digitalization and its scope in the functioning of generalized and local economic systems. The modern reality is that digital technologies are becoming a day-to-day tool and a customary way of the operation of the economy. They contribute to the improvement of economic business models and chains for creating added value of products (services), enhance strategic capabilities of business entities to establish efficient communicative interrelation with consumers, simplify the process of the implementation of technologies to disseminate environmentally and socially oriented directions of economic development of the country as a whole and its individual segments.

Socially-oriented, full-fledged and, at the same time, economically reasonable digitalization is becoming especially topical in the context of inclusive growth, which will contribute to the sustainable development of business and economy in Ukraine as a whole. In this regard, a bioeconomic platform for social growth should be singled out; this platform provides for the development of bioeconomy as a modern direction for promoting ecologization of social and environmental processes of human existence. Digitalization of bioeconomy through the lens of social digital transformation determines imperatives for the development of Ukrainian economy; and digitalization of the agricultural sector is considered to be one of the key tasks of the new government of our country. In this context, the use of digital marketing tools for disseminating the knowledge about the bioeconomic way of the operation of the economy in the society makes this research relevant, urgent and timely. 


\section{ANALYSIS OF THE LATEST RESEARCH AND PAPERS}

The research of basic questions of the development of digital marketing was considered in the works of many foreign (M. Auer, R. Bartels, B. Berman, H. Brian, J. Weibe, D. Wood, R. Goldsmith, J. Zaltman, A. Carroll, F. Kotler, R. Merton, L. Preston, J. Post, H. Hershgen, K. Schwab [1], R. Steyer and others) and domestic scientists (O. Boiko, N. Vasyltsiv [2], O. Hashutana, O. Grzbinenko [3], A. Hurenko [4], E. Kan, A. Kopeiko, Ye. Krykavskyi, O. Marchuk [5], O. Mnykh, M. Oklander, N. Rozhko and others). As for the in-depth research into the establishment of the bioeconomy, in the foreign scientific literature this issue was addressed by A. Bennett, Gerald A. Sarlson, D. Silberman, and V. Clark. Among the modern domestic scientists, the works of V. Baidala [6], V. Butenko [7], A. Proshchalykina [8], G. Makedon [9], M. Talavyra, O. Shubravska are worth mentioning. At the same time, the issue of involvement of digital marketing tools for the promotion of the bioeconomy in Ukraine has not been sufficiently and adequately substantiated yet, which determines the relevance of this research.

\section{PURPOSE FORMATION}

The purpose of the article is to provide theoretical substantiation to the role and possibilities of using digital marketing tools for promoting bioeconomy in Ukraine.

\section{DISCUSSION}

The intensification of the globalization fluctuations and the need to adapt to bifurcational shifts in economic processes emphasize the urgency of introducing conceptually new approaches to the formation of the strategy for sustainable economic development of Ukraine. The establishment of the bioeconomy occupies an important place in the list of incremental steps. Sustainable development isa general social pattern that envisages keeping the balance between meeting current needs of the mankind and protecting interests of future generations [9].This is a managed development based on a system approach and modern information technology that make it possible to model various probable scenarios quickly and qualitatively as well as to forecast their results with high probability and to take the most efficient action [10, p. 118].

The expediency of the above is determined by the relevant exogenous and endogenous factors that determine the process of the establishment of the bioeconomy in Ukraine, namely: 1) resource- and energy-intensive industries and technologies, export orientation towards raw materials along with over-concentration of production in industrial regions have dominated over many years in Ukraine; as a result, a completely inefficient and environmentally hazardous structure for managing the development has been formed; 2) the level of economic development and well-being of the population does not correspond to the natural, scientific and technical, agricultural and industrial potential of Ukraine as well as the qualification and educational level of the population, the sociohistorical and cultural traditions of the Ukrainian people; 3) Ukraine has international commitments on sustainable development, as defined by UN strategic documents; 4) the basis for the implementation of innovative transformations in Ukraine towards sustainable development is the Association Agreement between Ukraine and the European Union; 5) Ukrainian scientists have prepared a scientific substantiation for Ukraine's transition to sustainable development and appropriate public support for this process has been formed [11].

The modern concept of sustainability involves a combination of three main aspects, in particular, the enhancement of the environment, the harmonious development of production and the well-being of the population, and the improvement of its standard of living. For Ukraine, given the low rate of socioeconomic development and the constant increase of environmental problems, such a model of development is extremely important. The current situation in the country needs a renewed direction for the development of society, which will form new relations between people and nature. The model for the formation of the bioeconomic direction of society development is presented in Fig. 1.

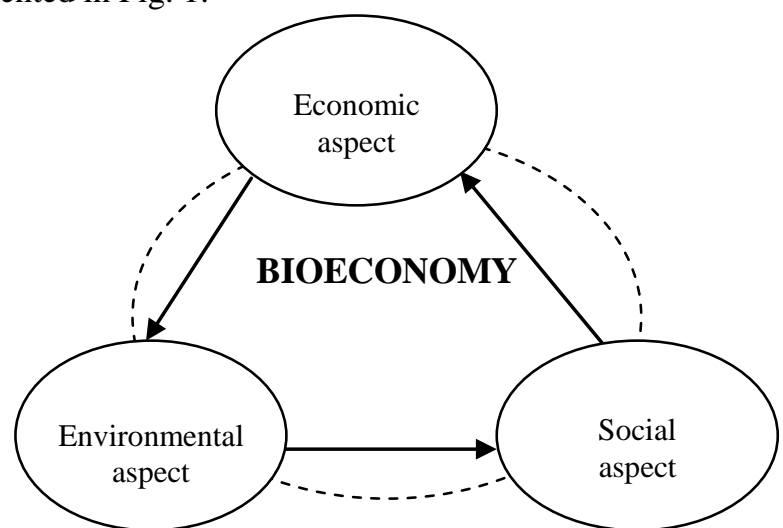

Fig. 1. Formation of the bioeconomic direction of society development

The rapid development of industry and transport, which provided for a comfortable life of the current civilization through creating public goods for the population, has created new challenges. Increasing the production volumes in order to meet the unlimited needs of society, people in the course of their economic activity intensively deplete natural fossil resources. A considerable number of goods are produced and consumed in order to satisfy the whims of modern civilization, which causes another problem, the increase in waste. Humanity faced these problems in the 21 st century, because before 1920 people produced goods from natural raw materials and consumed in limited quantities. The development of the petrochemical industry and the mass production of synthetic materials contributed to the change in natural raw materials. Consequently, the consumption of petrochemical products caused social, medical and environmental problems.

Being aware of the extent of the problems, the whole world is actively returning to bioeconomic development, where production is carried out on a biological basis. There is no understanding of the problem in Ukraine now. Thus, it requires widespread publicizing through conveying to the

Published By:

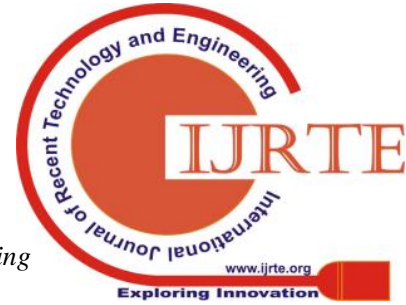


society the importance of changing the concept of further development, which will follow not only the human-centric paradigms but also the ecocentric ones. It is important to communicate to modern society the need to find a renewed path of their development, since the present path will lead mankind only to self-destruction. Awareness of the problems and the need for bioeconomic foundations of development is possible only with the widespread publicizing through modern high technologies. Since modern post-industrial society is characterized by the deep theoretical knowledge and the dissemination of information and communication technologies, the use of digital marketing tools for promoting bioeconomy in our country is accessible, modern and extremely important.

The research has shown that such leading countries of the world as Great Britain, New Zealand, Singapore, UAE, Estonia, Japan, Israel and others have taken a clear course on the digitization of key areas of the economy in recent years. Throughout the world, the share of the traditional economy is gradually decreasing against the backdrop of active digitization of economic processes, which creates significant benefits for the country as a whole (as a socioeconomic system of the macro level) and business in particular (as a socioeconomic system of the micro level). Instead, in Ukraine, whose outsourced IT-specialists have already digitized half of the world, it is only now that at the national level the necessity to use digitization as an effective marketing tool for the dissemination of modern technologies of economic development is supported, especially on bioeconomic grounds.

In the established format, digitization refers to the transformation, penetration of digital technologies to optimize and automate business processes and improve communication with consumers [2]. In turn, management of business processes within economic systems is accompanied by various problems, including the complementary relationship between business process management and their implication in corporate value. Digitization facilitates the processes of forming a system of effective multi-vector and reverse communication flows.

The progressive development of civilization is particularly noticeably accompanied by the acceleration of the use of tools and channels of digital marketing, which originated in the $90-\mathrm{s}$ of 20th century. The free encyclopedia defines digital marketing (interactive marketing) as a generic term used to refer to the targeted and interactive marketing of goods and services, using digital technologies and channels to attract and retain potential customers [12]. The main tasks of digital marketing are to promote the brand and increase sales by means of various technologies. It includes an entire toolkit of marketing tactics to promote products, services and brands. In the context of this research, it is suggested to consider bioeconomy as a brand that should be promoted through digital marketing tools.

Apart from mobile technology, traditional television and radio, digital marketing techniques use the Internet as the primary medium of communication [15]. Digital marketing is rather often identified with internet marketing. However, digital marketing includes internet marketing, but goes beyond the Internet. Internet marketing includes SEO-promotion of the site, context, webinars, etc., that is, all channels that are available to the user only on the Internet. Digital marketing includes all of the above and also advertising and promotion on any digital media offline. That is, it involves digital communication that takes place both online and offline [5, p. 297].

Thus, digital marketing is a comprehensive promotion system that configures a wide toolkit of marketing tools and channels [13]. Its fundamental concept consists ina customer-centric approach. The most common tools that are becoming commonplace and increasingly relevant in the context of globalization for bioeconomic branding include diverse advertising across all available applications, messages, online entertainment, or online training; SMS and MMS; SMM-marketing in social networks; content marketing; indoor and outdoor advertising on interactive LED screens, self-service terminals and other up-to-date locations; SEO and SEM - search engine marketing in social networks; contextual advertising, banners; email marketing; affiliate marketing; viral marketing, etc.

The most popular forms of digitization include search engine promotion, contextual and teaser advertising, display and banner advertising, opportunities for promotion via social media and blog, mobile application development for smartphones, tablets and other media, viral advertising [12]. Digital marketing channels are the Internet and devices that provide access to the Internet (PCs, laptops, tablets, smartphones, etc.), mobile devices; local networks (Extranet, Intranet); digital TV; interactive screens, POS-terminals (Fig 2).

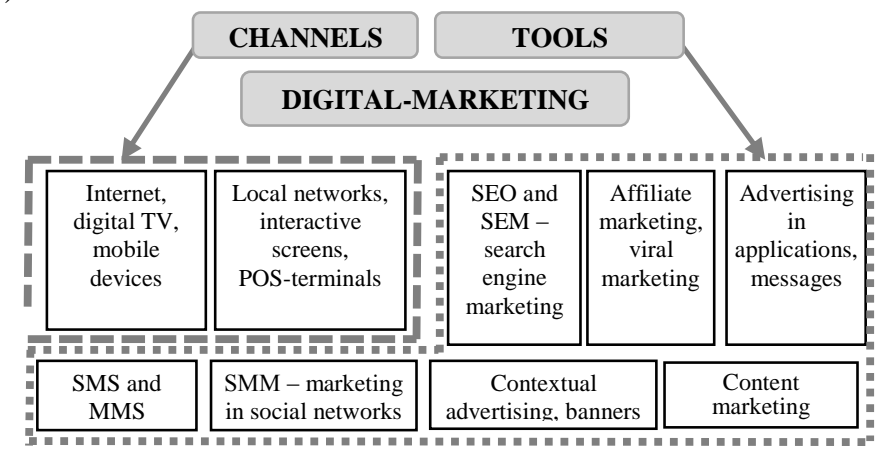

Fig 2. Channels and tools of digital marketing

Source: formed on the basis of $[12 ; 15]$.

These tools can be grouped according to opportunities and sources of financial support, namely: paid resources (absolutely all manifestations in digital that necessarily require payment); own resources (websites, social media pages that are business-owned) and earned resources (free or purchased communication channels, such as rumors, information boom, etc.) [15]. This approach makes it possible to form an objective picture of the most appropriate (first of all financially) conditions for attracting digital tools and effective managerial decision-making regarding the implementation of bioeconomic principles of business development. The advantages of digital marketing, from the standpoint of its application for the promotion of the bioeconomy in Ukraine, are summarized in Table I. 
Table I. The content of digital marketing from the standpoint of promoting bioeconomy

\begin{tabular}{|c|c|}
\hline Indicator & Substantiation \\
\hline $\begin{array}{l}\text { Sphere of } \\
\text { influence on the } \\
\text { target audience }\end{array}$ & online+offline \\
\hline $\begin{array}{l}\text { Dissemination } \\
\text { channels }\end{array}$ & $\begin{array}{l}\text { All types of digital channels - the } \\
\text { Internet, mobile devices; local } \\
\text { networks; digital TV; email; } \\
\text { interactive screens, etc. }\end{array}$ \\
\hline Target audience & $\begin{array}{l}\text { Science, production, business. } \\
\text { Everyone employed in the } \\
\text { economic sector with a focus on } \\
\text { the socially oriented development }\end{array}$ \\
\hline $\begin{array}{l}\text { Dissemination } \\
\text { tools }\end{array}$ & $\begin{array}{l}\text { Advertising; SMS and MMS; } \\
\text { SMM-marketing; } \\
\text { marketing; indoor and outdoor } \\
\text { advertising; SEO and SEM - } \\
\text { search engine marketing in social } \\
\text { networks; contextual advertising, } \\
\text { banners; affiliate marketing; viral } \\
\text { marketing, etc. }\end{array}$ \\
\hline Key advantages & $\begin{array}{l}\checkmark \text { interactive character (active } \\
\text { encouragement of a user } \\
\text { (economic actors) to interact with a } \\
\text { brand (bioeconomy); } \\
\checkmark \text { unlimited promotion (no } \\
\text { territorial restrictions during the } \\
\text { achievement of marketing goals); } \\
\checkmark \text { accessibility of information } \\
\text { resources; } \\
\checkmark \text { the distribution of a marketing } \\
\text { product (bioeconomy) in the } \\
\text { business space leads to the active } \\
\text { involvement of the target audience; } \\
\checkmark \text { specification (identification of a } \\
\text { highly specialized audience) }\end{array}$ \\
\hline
\end{tabular}

It is important to note that the views of current researchers and practitioners (both domestic and foreign) on the necessity of application and the possibility of forming an effect from a particular tool or channel of digital marketing are different, and often even contradictory. In our opinion, this is explained by a number of objective and subjective circumstances that determine the immanent nature of the process of information dissemination among the subjects of economic relations. Exogenous and endogenous factors also have a significant impact on the modeling and forecasting of business processes within individual marketing systems against the background of the variability and unpredictability of the external environment. In turn, the outlines and features of such systems are a kind of indicator for the formation of appropriate toolset for informational promotion of a marketing product (bioeconomy) among the public. The expediency of using a particular digital marketing channel is determined by the specific conditions, opportunities, needs and tasks of the economic entities with clearly defined strategic positions and own vision of the strategic mission in the field of intensification of bioeconomic processes. It is important not to cover too many channels, but to focus on the goals and opportunities of a particular business, because there are no universal solutions.

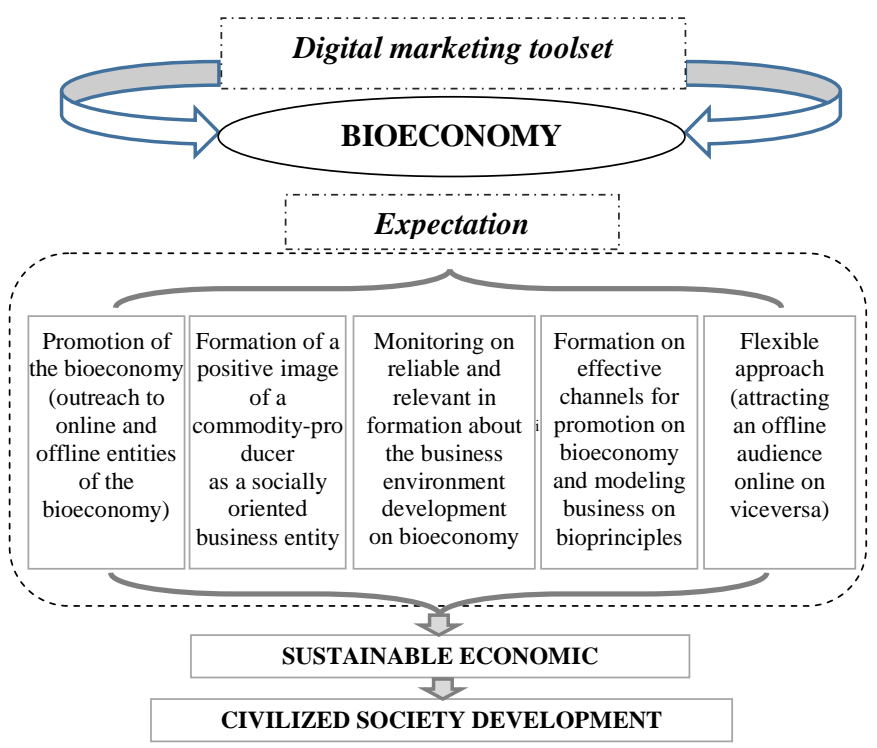

Fig. 3. Effects from the implication of digital marketing to promote the bioeconomy

Source: authors' research.

The promotion of the bioeconomic direction will make it possible to achieve energy independence, to produce high-quality food and non-food products, to increase the level of food security, to create new jobs, to increase the standard of living of the population (social aspect); to preserve biodiversity, to enhance the environment, to use fossil fuels sparingly, and to mitigate the effects of climate change (environmental aspect); to restore innovative bio-production, to increase the competitive ability of products and to promote the economic development of the country as a whole (economic aspect).

Active promotion of the need to establish bioeconomy in Ukraine involves outreaching online and offline entities of the bioeconomy. The involvement of the state is of particular importance, since the implementation of the bioeconomic direction requires the formation of an appropriate legislative framework as well as the creation of institutional and economic conditions for the development of the bioindustry.

Publicizing of the possibility of innovative bio-production is important for creating a positive image of bioproducers as socially-oriented business entities. Its environmental friendliness and safety should force the society to reconsider their tastes and preferences towards consuming exclusively healthy food, bioproducts, which has excellent competitive advantages over other food and non-food goods as they are made from organic raw materials.

The dissemination of credible and relevant information about the business environment for the establishment of bioeconomy will help to create a favorable investment climate in this industry, since the bioindustry requires significant investment. Biotechnological processes and the constant search for innovative ideas help to transform biological raw materials into bioproducts, which cannot be realized without additional funding and state support for the country's innovation potential. 
Benchmarking is the most effective tool that will help to effectively model business processes at an enterprise that intends to produce bio-based products. Studying the experience of advanced producers of bioproducts is possible only through the use of the abovementioned channels of promotion of the bioeconomy. The use of benchmarking will make it possible to find, investigate and implement or improve own production in accordance with the best practices in the bioindustry.

Awareness of all potential stakeholders and their involvement in the bioeconomic direction is possible through the online market, which provides free access to the necessary goods and an offline audience that attracts targeted listeners. It also helps to unite the scientific community freely, which plays a key role in promoting the bioeconomy.

\section{CONCLUSIONS}

The implication of digital marketing tools and channels for the promotion of the bioeconomy will help to consolidate the efforts of all business entities to create favorable conditions for a bio-based business. This will make it possible to preserve a healthy nation and consume useful goods, increase the well-being of the population, enhance the environment and preserve biodiversity, and also produce competitive products. This will contribute to achieving sustainable development of the Ukrainian economy and will give impetus to the formation of the civilized development of a modern society, characterized by a deep and complementary interconnection between people and nature.

\section{REFERENCES}

1. K. Schwab. The Fourth Industrial Revolution: what it means, how to respond. Available: https://www.weforum.org/agenda/2016/01/the-fourth-ind ustrialrevolution-what-it-meansand-how-to-respond/.

2. N. M. Vasyltsiv, N. Ia. Rozhko (2018). Current trends in digital marketing. Economy and society. Vol. 15. P. 232-236.

3. M. Hrybinenko. Digitizing the economy in the new paradigm on digital transformation. Available: file:///C:/Users/Admin/Downloads/3523-12970-1-PB.pdf

4. A. V. Hurenko, O. V. Hashutana (2018). Tendency of development of management systems in conditions of business digitization in Ukraine. Economy and society. Vol. 19. P. 739-745.

5. O. O. Marchuk (2018). Digital marketing as an innovative management tool. Economy and society. Vol.17. P. 296-299.

6. V. V. Baidala (2013). Bioeconomy in Ukraine: current state and prospects. Collection of scientific works of the Taurida State Agrotechnological University (Economic Sciences). Vol. 1(3). P. 22-28.

7. V. M. Butenko (2016). Bioeconomy as a mechanism for achieving sustainable development goals. Bulletin of Agrarian Science of the Black Sea. Vol. 1. P. 19-28.

8. A. M. Proshchalykina (2016). Prerequisites for the formation and development of bioeconomics. An efficient economy. Vol. $12 . \quad$ Available: http://www.economy.nayka.com.ua/?op=1\&z=5314.

9. H. M. Makedon, M. P. Taoavyria. Bioeconomics as a basis for sustainable development of Ukraine. Available: http://www.irbis-nbuv.gov.ua/cgi-bin/irbis_nbuv/cgiirbis 64.exe?C21COM=2\&I21DBN=UJRN\&P21DBN=UJR N\&IMAGE FILE DOWNLOAD $=1 \&$ Image file name

$=$ PDF/nvnau_econ_2013_181(6)_27.pdf.

10. F. Stewart, E. Samman (2018). Advancing Human Development : Theoryand Practice. Available: http://hdr.undp.org/en/content/advancing-human-develop ment-theory-and-practice.

11. Sustainable Development Strategy of Ukraine until 2030 (draft).

Available:https://www.undp.org/content/dam/ukraine/do cs/SDGreports/UNDP_Strategy_v06-optimized.pdf.

12. O. Kovalchuk, O. Hyryla (2019). Modeling of economic dimensions of global sustainable development. Bulletin of the Ternopil National Economic University. Vol. 1. P. $117-130$

13. Digital marketing. Free Encyclopedia. Available: https://uk.wikipedia.org/wiki/\%D0\%A6\%D0\%B8\%D1\% 84\%D1\%80\%D0\%BE\%D0\%B2\%D0\%B8\%D0\%B9_\% D0\%BC\%D0\%B0\%D1\%80\%D0\%BA\%D0\%B5\%D1\%8 2\%D0\%B8\%D0\%BD\%D0\%B3.

14. Digital Marketing. [Online]. Available: https://www.techopedia.com/definition/27110/digital-ma rketing.

15. Aimbulance - marketing agency. Available: https://aimbulance.com/ua/.

\section{AUTHORS PROFILE}

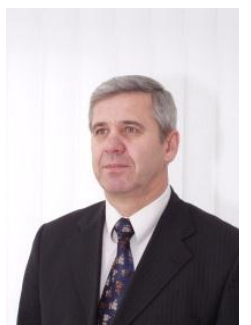

enterprises.

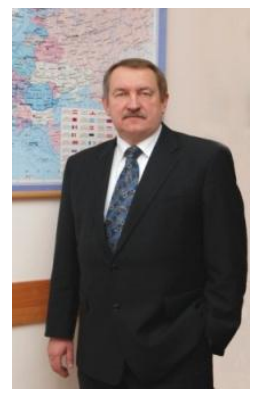

Zinovchuk V. V.: Dr. habil. in Economics, Professor, Head of the of Marketing Department, Zhytomyr National Agroecological University of Ukraine, Zhytomyr, Ukraine

Published more than 230 scientific and methodological works

Honored Worker of Science and Technology of Ukraine, Honorary Worker of Productivity System of Agroindustrial Complex of Ukraine (II and III degrees)

Member of the Scientific and Methodological Commission on Business, Management and Law of the Ministry of Education and Science of Ukraine, subcommittee 075 "Marketing" (Order of the Ministry of Education and Science of Ukraine No. 375 of April 6, 2015).

Research work: Agricultural cooperation and vertical integration, international agribusiness marketing, strategic rural development planning.

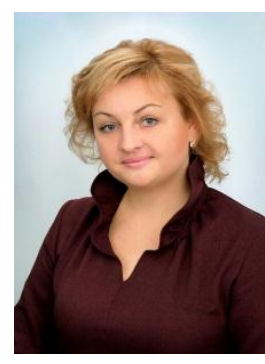

Tarasovych L. V.: Ph. D. in Economics, Associate Professor, doctoral student at the Marketing Department, Scientific Secretary of the Specialized Academic Council D 14.083.02 on the dissertation defense for the degree of Doctorate (Candidate) Degree in Economics in the specialties 08.00.03 "Economics and Management of National Economy" and 08.00.04 "Economics and Management of Enterprises (by economic activities)". Zhytomyr National Agroecological University of Ukraine, Zhytomyr, Ukraine

Published more than 100 scientific and methodological works, including 3 study guides in co-authorship and 5 works in international databases Scopus and Web of Science

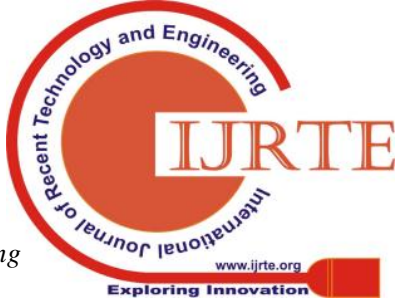


In 2017, was received the Acknowledgment of the Ministry of Education and Science of Ukraine for many years of diligent work, a significant personal contribution to the training of highly qualified specialists and fruitful scientific and pedagogical activity.

Research work: the development of a rural economy based on marketing.

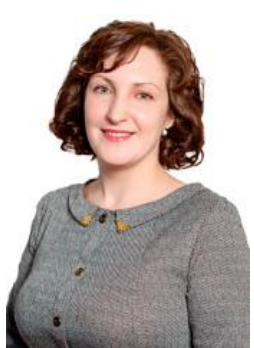

Yaremova M. I.: Ph.D. in Economics, Associate Professor, doctoral student at the Department of Economics and Entrepreneurship, Zhytomyr National Agroecological University of Ukraine, Zhytomyr, Ukraine

Published more than 75 scientific and methodological works, including 4 monographs in co-authorship and 3 works in international science-based databases Scopus and Web of Science

Research work: bioeconomics and bio-based products, food security and food sovereignty. 